\title{
Gestational diabetes mellitus diagnosed with single test glucose screening test and its outcome in a tertiary hospital in South India
}

\author{
Sunita T. H.*, Rathnamala M. Desai, Asha Neravi
}

Department of Obstetrics \& Gynaecology, SDM medical college and hospital, Dharwad, Karnataka, India

Received: 29 September 2015

Accepted: 02 November 2015

\author{
*Correspondence: \\ Dr. Sunita T. H., \\ E-mail: srposdm@yahoo.com
}

Copyright: $\odot$ the author(s), publisher and licensee Medip Academy. This is an open-access article distributed under the terms of the Creative Commons Attribution Non-Commercial License, which permits unrestricted non-commercial use, distribution, and reproduction in any medium, provided the original work is properly cited.

\begin{abstract}
Background: 1) To assess maternal and neonatal outcomes after screening, diagnosing and treating GDM. 2) Role of single test glucose screening test (GST) in diagnosing gestational diabetes mellitus (GDM) in our population.

Methods: A one year retrospective study of women diagnosed with and treated for GDM from Jan 2014 to Dec 2014 at SDM medical college and hospital, Dharwad, Karnataka, India. Case records were retrieved to collect data on maternal and neonatal outcome, glycemic control and diabetic management. Single test GST, as per the latest DIPSI guideline was the test used to diagnose GDM i.e. 75 gm of glucose was given to all pregnant women between $24-34$ weeks of pregnancy, irrespective of the last meal and time of the day and after two hours, plasma glucose was estimated. Women with a 2-hr plasma glucose value of $>140 \mathrm{mg} / \mathrm{dl}$ were diagnosed to have GDM and were not subjected further for oral glucose tolerance test (OGTT). In women with high risk factors for GDM, the test was performed in the $\mathrm{I}^{\mathrm{st}}$ trimester or at their first visit to the hospital.

Results: All booked women in the study period underwent GST i.e. we could do universal screening .The incidence of GDM was $4.8 \% .147$ women were diagnosed to have GDM out of 3050 women screened for GDM. Of the affected women, $74.1 \%$ were managed with diet alone and $24.9 \%$ received insulin treatment. Good glycemic control improved both maternal and neonatal outcome. Poor glycemic control and presence of preeclampsia were risk factors for maternal and neonatal complications.

Conclusions: Single test GST is a patient friendly and effective approach to screen women for GDM especially in high risk ethnic population. Timely and aggressive management helps improve maternal and neonatal outcomes and also decrease the future risk of development of diabetes both in the mother and the fetus.
\end{abstract}

Keywords: GDM, GST, OGTT

\section{INTRODUCTION}

The prevalence of gestational diabetes mellitus (GDM) is increasing globally, more so in developing countries including India where the prevalence is estimated to range between $3.8 \%$ to $21 \%$. ${ }^{1}$ GDM is not only associated with maternal and fetal complications but also increases the likelihood of subsequent diabetes in the mother as well as the fetus. Managing GDM is like primary prevention of diabetes for the next generation. The prevalence of DM is increasing at an alarming rate of > $120 \%$ from 135 million in 1995 to 300 million in $2025{ }^{2}$
Universal screening for GDM is necessary and will help India become "the world's diabetes care capital" instead of "diabetes capital of the world". Fasting plasma glucose estimation is not necessary for screening WHO is not in favour of estimating fasting blood glucose for screening. A single test procedure with $75 \mathrm{gm}$ of glucose in the non fasting state was found to be similar to WHO oral glucose tolerance test (OGTT) in diagnosing GDM by V. Seshaih et al in their study in Indian population. ${ }^{3}$ So we have adopted the single test glucose screening test (GST) done in the non - fasting state for screening GDM in our population. 


\section{METHODS}

A one year retrospective study of women diagnosed with and treated for GDM from Jan 2012 to Dec 2012 at SDM medical college and hospital, Dharwad. Case records were retrieved to collect data on maternal and neonatal outcome, glycemic control and diabetic management. Single test GST, as per latest DIPSI guideline was used to diagnose GDM i.e. 75 gm of glucose was given to all pregnant women between 24 - 34 weeks of pregnancy, irrespective of the last meal and time of the day and after two hrs plasma glucose was estimated. In women with high risk factors for GDM, $\mathrm{I}^{\text {st }}$ trimester screening or at their first visit to the hospital. Patients with preexisting DM were excluded. 2 hr plasma glucose value of $>140$ $\mathrm{mg} / \mathrm{dl}$ à GDM and were not subjected further for OGTT. Medical nutrition therapy (MNT) was advised. FBS and PPBS were done after two weeks.

High GST values and advanced gestational age patients were preferably admitted.

Supervised diet therapy and complete blood sugar profile was done.

- $\quad$ Fasting capillary glucose (FCG),

- two hour post breakfast,

- pre lunch, post lunch,

- $\quad$ pre dinner and post dinner capillary glucose values.

The target values:

- Fasting values - 90 to $100 \mathrm{mg} / \mathrm{dl}$

- 2 hour postprandial values - 120 to $140 \mathrm{mg} / \mathrm{dl}$.

- If most of the values were high on repeated testing, patients were started on Insulin therapy.

\section{RESULTS}

3050 booked patients underwent screening for GDM and delivered at this institution during the study period \&
$147(4.8 \%)$ were diagnosed to have GDM. Maternal and fetal outcomes were analysed. Maternal parameters like development of preeclampsi, PROM, preterm labour, mode of delivery, induction of labour glycemic control, medical nutrition therapy (MNT) \& need for insulin with MNT were studied. Fetal parameters like macrosomia, fetal growth restriction, hyperbilirubinemia, hypoglycemia, admission to NICU, APGAR score were studied. The most common age group of women with GDM was between $25-35$ years ie $83.67 \%$. $14 \%$ of women were $>35 \mathrm{yrs}$ and only $2 \%$ of women were in the age group of 19-24 yrs.

About $42.81 \%$ of women were overweight. 109(74.1\%) women were managed with MNT with good glycemic control. 38 (24.9\%) women needed insulin therapy; seven women had poor glycemic control even with insulin. The overall gestational age at delivery was 38 weeks. Induction of labour was done in $44.89 \%$. The rate of cesarean section in women with GDM was $45.57 \%$, the rate increased to $76.31 \%$ in women requiring insulin. The rate of macrosomia among GDM women with uncontrolled sugars was $85.71 \%$ but in controlled group it was $10.52 \%$. Perinatal mortality rate in our series was found to be $3.4 \%$. There were two intrauterine deaths in patients on insulin with poor control.

One patient with GDM on insulin and severe preeclampsia had spontaneous preterm delivery of a fresh stillborn fetus.

- There were two neonatal deaths,one had congenital heart disease and died after 15 days of NICU care.

- The second baby had hydrocephalus, was an induced preterm delivery and incidentally the mother had mild GDM.

- Preeclampsia was seen in about $10.88 \%$ of women with GDM and had higher rates of induced labour, admission to NICU, FGR including two perinatal deaths.

Table 1: Maternal outcome among women with GDM treated by MNT alone and insulin.

\begin{tabular}{|c|c|c|c|c|c|}
\hline Outcome & $\begin{array}{l}\text { MNT Alone } \\
\text { Number :109 }\end{array}$ & $\%$ & $\begin{array}{l}\text { Insulin } \\
\text { Number } 38\end{array}$ & $\%$ & p value \\
\hline Preeclampsia & 06 & $5.50 \%$ & 10 & $\begin{array}{l}26.31 \% \\
73.69\end{array}$ & $\begin{array}{l}\chi^{2}=12.58 \\
0.00039\end{array}$ \\
\hline Cesarean Section & 38 & $34.86 \%$ & 28 & $76.32 \%$ & $\begin{array}{l}\chi^{2}=19.52 \\
0.000000995\end{array}$ \\
\hline PROM & 10 & 9.1 & 9 & 23.68 & $\begin{array}{l}\chi^{2}=5.27 \\
0.021684\end{array}$ \\
\hline Induction of labour & 54 & 49.54 & 12 & 31.57 & $\begin{array}{l}\chi^{2}=3.67 \\
0.055244\end{array}$ \\
\hline Preterm delivery & 3 & 2.75 & 5 & $18.42 \%$ & $\begin{array}{l}\text { Fischer exact test } \\
\text { statistic }=0.028 \\
<0.05\end{array}$ \\
\hline
\end{tabular}


Table 2: Fetal outcome among women with GDM treated by MNT alone and insulin.

\begin{tabular}{|c|c|c|c|c|c|}
\hline Outcome & $\begin{array}{c}\text { MNT Alone } \\
\text { Number :109 }\end{array}$ & $\%$ & $\begin{array}{c}\text { Insulin } \\
\text { Number } 38\end{array}$ & $\%$ & p value \\
\hline Macroso-mia & 17 & $15.59 \%$ & 10 & 26.31 .69 & $\begin{array}{l}\chi^{2}=2.16 \\
0.141702\end{array}$ \\
\hline $\begin{array}{l}\text { Jaundice requiring } \\
\text { photothe-rapy }\end{array}$ & 11 & 10.09 & 09 & 23.68 & $\begin{array}{l}\chi^{2}=4.43 \\
0.0353\end{array}$ \\
\hline Hypogly-cemia & 03 & $2.75 \%$ & 02 & 5.26 & $\begin{array}{l}\text { Fischer exact test statistic } \\
=0.6041 \\
>0.05\end{array}$ \\
\hline $\begin{array}{l}\text { APGAR score at } 1 \mathrm{~min} \\
<7\end{array}$ & 03 & $2.75 \%$ & 01 & 2.63 & $\begin{array}{l}\text { Fischer exact test statistic } \\
=1.0 \\
>0.05\end{array}$ \\
\hline Admission to NICU & 07 & 6.42 & 06 & 15.78 & $\begin{array}{l}\chi^{2}=3.07 \\
0.079894\end{array}$ \\
\hline FGR & 09 & 8.25 & 12 & 31.58 & $\begin{array}{l}\chi^{2}=12.52 \\
0.000403\end{array}$ \\
\hline Death & 01 & 0.92 & 4 & 10.52 & $\begin{array}{l}\text { Fischer exact test statistic } \\
=0.016 \\
<0.05\end{array}$ \\
\hline Still birth & - & - & 03 & $7.9 \%$ & \\
\hline Neonatal death & 01 & 0.92 & 01 & 2.63 & $\begin{array}{l}\text { Fischer exact test statistic } \\
=0.4515 \\
>0.05\end{array}$ \\
\hline Shoulder dystocia & 02 & 1.83 & 0 & 0 & \\
\hline
\end{tabular}

Table 3: Characteristics of women with GDM

\begin{tabular}{|c|c|c|c|c|c|}
\hline Parity & $\begin{array}{c}\text { MNT Number: } \\
109\end{array}$ & $\begin{array}{l}\text { MNT } \\
\%\end{array}$ & $\begin{array}{c}\text { Insulin } \\
\text { Number:38 }\end{array}$ & $\begin{array}{c}\text { Insulin } \\
\%\end{array}$ & p value \\
\hline Primi & 39 & 35.77 & 08 & 21.05 & $\chi^{2}=0.09$ \\
\hline Multi & 70 & 64.23 & 30 & 78.95 & 0.093692 \\
\hline \multicolumn{6}{|l|}{ Maternal age } \\
\hline $20-24 y r s$ & 03 & 2.76 & 10 & 26.32 & $\chi^{2}=30.83$ \\
\hline $25-35 y r s$ & 102 & 93.57 & 21 & 55.26 & $<0.00001$ \\
\hline$>35 y r s$ & 04 & 3.67 & 07 & 18.42 & \\
\hline \multicolumn{6}{|l|}{ Maternal BMI } \\
\hline$<19$ & 02 & 1.83 & 07 & 18.42 & \\
\hline $20-25$ & 63 & 57.79 & 05 & 13.15 & $\chi^{2}=34.15$ \\
\hline $25-29$ & 41 & 37.62 & 20 & 52.63 & 0.000123 \\
\hline$>30$ & 03 & 2.76 & 06 & 15.78 & \\
\hline
\end{tabular}

\section{DISCUSSION}

- Indians are at an increased risk of developing GDM and DM.

- Women with a history of GDM are more likely to get diabetes later as are their children.

- So GDM women are an ideal group for the primary prevention of DM.

- This means that our women should undergo universal screening for GDM and for this we need a simple, patient friendly test.

- So we have adopted the single test GST done in the non - fasting state for screening GDM in our population.

- The nonfasting $2 \mathrm{hrs}$ post 75 gms of glucose concentration strongly predicts adverse outcome in the mother as well as the fetus.

- All antenatal patients attending the OBG OPD during the study period underwent screening for GDM.so we could do universal screening for GDM.

- This will help for the primary prevention of DM in our country in addition to reduction of perinatal and maternal complications of undiagnosed GDM. 
Table 4: Outcome of women on insulin.

\begin{tabular}{|c|c|c|c|c|c|}
\hline Outcome & $\begin{array}{l}\text { Good Control } \\
\text { No: } 31\end{array}$ & $\%$ & $\begin{array}{l}\text { Poor Control } \\
\text { No: } 07\end{array}$ & $\%$ & $p$ value \\
\hline Preecla-mpsia & 07 & 22.58 & 03 & 42.85 & $\begin{array}{l}\text { Fischer exact test } \\
\text { statistic }=0.3510 \\
>0.05\end{array}$ \\
\hline Cesarean section & 23 & 74.19 & 06 & 85.71 & $\begin{array}{l}\text { Fischer exact test } \\
\text { statistic }=0.66 \\
>0.05\end{array}$ \\
\hline Preterm delivery & 02 & 6.45 & 03 & 42.85 & $\begin{array}{l}\text { Fischer exact test } \\
\text { statistic }=0.0346 \\
<0.05\end{array}$ \\
\hline Macrosomia & 04 & 12.9 & 06 & 85.71 & $\begin{array}{l}\text { Fischer exact test } \\
\text { statistic }=0.005 \\
<0.05\end{array}$ \\
\hline Jaundice & 04 & 12.9 & 05 & 71.42 & $\begin{array}{l}\text { Fischer exact test } \\
\text { statistic }=0.0042 \\
<0.05\end{array}$ \\
\hline Hypogly-cemia & - & - & 02 & 28.57 & \\
\hline $\begin{array}{l}\text { APGAR at } 1^{\text {st }} \\
\min <7\end{array}$ & - & - & 01 & 14.28 & \\
\hline $\begin{array}{l}\text { Admission to } \\
\text { NICU }\end{array}$ & 02 & 6.45 & 05 & 71.42 & $\begin{array}{l}\text { Fischer exact test } \\
\text { statistic }=0.0008 \\
<0.05\end{array}$ \\
\hline FGR & 09 & 29.03 & 03 & 42.85 & $\begin{array}{l}\text { Fischer exact test } \\
\text { statistic }=0.6560 \\
>0.05\end{array}$ \\
\hline Perinatal Death & 01 & 3.22 & 04 & 57.15 & $\begin{array}{l}\text { Fischer exact test } \\
\text { statistic }=0.0022 \\
<0.05\end{array}$ \\
\hline
\end{tabular}

Universal screening for GDM plays an important role in this era of increasing obesity and sedentary life style which are important risk factors for GDM along with our high risk ethnic race.

MNT is the main treatment for GDM. This was seen in our study as well, $74.1 \%$ of women were treated with diet alone.

Macrosomia is an important complication of GDM. Inspite of universal screening in our series, macrosomia was seen in $13.60 \%$ of women.

Fetal hyperinsulinemia occurs as early as $16^{\text {th }}$ week of pregnancy and thus maternal hyperglycemia in the $\mathrm{I}^{\text {st }}$ trimester should be avoided to reduce the risk of macrosomia.

Hence screening as early as $16^{\text {th }}$ week is advisable in patients with average risk factors for GDM.

Fetal outcome does not vary significantly among women who are treated with diet alone or with diet and insulin with good glycemic control.
Several studies suggest an increased rate of preeclampsia among women with GDM. ${ }^{4}$

Maternal diabetes and preeclampsia is associated with poor perinatal outcome.

In our series $10.55 \%$ of the women with GDM developed preeclampsia which is similar to study done by Lao TT et al. 5

\section{CONCLUSIONS}

Single test GST is a patient friendly and effective approach to screen women for GDM especially in high risk ethnic population where universal screening is required.

Timely and aggressive management helps improve maternal and neonatal outcome and also decrease the future risk of development of diabetes both in the mother and the fetus. 
Table 5: Maternal and fetal outcome according to presence / absence of preeclampsia among women with GDM.

\begin{tabular}{|c|c|c|c|c|c|}
\hline Outcome & $\begin{array}{l}\text { Preecla-mpsia } \\
: 16\end{array}$ & $\%$ & $\begin{array}{l}\text { Without } \\
\text { Preeclampsia } \\
: 131\end{array}$ & $\%$ & p value \\
\hline $\begin{array}{l}\text { Induction of } \\
\text { labour }\end{array}$ & 12 & 75 & 76 & 58 & $\begin{array}{l}\text { Fischer exact test statistic } \\
=0.28 \\
>0.05\end{array}$ \\
\hline Cesarean section & 07 & 43.75 & 60 & 45.80 & $\begin{array}{l}\chi^{2}=0.02 \\
0.876394\end{array}$ \\
\hline Preterm delivery & 04 & 25 & 04 & 3.05 & $\begin{array}{l}\text { Fischer exact test statistic } \\
=0.0052 \\
<0.05\end{array}$ \\
\hline Macrosomia & 01 & 6.25 & 26 & 19.84 & $\begin{array}{l}\text { Fischer exact test statistic } \\
=0.31 \\
>0.05\end{array}$ \\
\hline Jaundice & 09 & 56.25 & 11 & 8.39 & $\begin{array}{l}\chi^{2}=27.78 \\
0.000000136\end{array}$ \\
\hline $\begin{array}{l}\text { APGAR score at } \\
1 \mathrm{~min}<7\end{array}$ & 02 & 12.5 & 02 & 1.52 & $\begin{array}{l}\text { Fischer exact test statistic } \\
=0.0588 \\
<0.05\end{array}$ \\
\hline $\begin{array}{l}\text { Admission to } \\
\text { NICU }\end{array}$ & 06 & 37.5 & 07 & 5.34 & $\begin{array}{l}\chi^{2}=18.29 \\
0.0000019\end{array}$ \\
\hline Hypogly-cemia & 02 & 12.5 & 03 & 2.29 & $\begin{array}{l}\text { Fischer exact test statistic } \\
=0.0917 \\
>0.05\end{array}$ \\
\hline FGR & 10 & 62.5 & 11 & 8.39 & $\begin{array}{l}\chi^{2}=34.08 \\
0.000000000000528\end{array}$ \\
\hline Perinatal Death & 02 & 12.5 & 03 & 2.2 & $\begin{array}{l}\text { Fischer exact test statistic } \\
=0.0917 \\
>0.05\end{array}$ \\
\hline Neonatal death & 01 & $1.83 \%$ & $\begin{array}{l}01 \\
37\end{array}$ & - & 0.4515 \\
\hline $\begin{array}{l}\text { Shoulder } \\
\text { dystocia }\end{array}$ & 02 & - & $\begin{array}{l}0 \\
38\end{array}$ & - & 1.0000 \\
\hline
\end{tabular}

Funding: No funding sources

Conflict of interest: None declared

Ethical approval: The study was approved by the

Institutional Ethics Committee

\section{REFERENCES}

1. Seshiah V, Balaji V, Balaji MS. Pregnancy and diabetes scenario around the world: India. Int J Gynaecol Obstet. 2009;104(suppl):535-8.

2. Avi Ben - Haroush, Yariv Yogev, Moshe Hod. Epidemiology of gestational diabetes mellitus. Textbook of Diabetes and Pregnancy. 2003;85-6.

3. Anjalakshi C, Balaji MS, Ashalata S, SeshiahV, Sheela S, Arthi T. A single test procedure to diagnose gestational diabetes mellitus. Acta Diabetol. 2009; 46:51-4.

4. Schmidt MI, Duncan BB, Reichelt AJ, Branchtein L, Matos MC, Costa e Forti A. Gestational diabetes mellitus diagnosed with a 2-h $75 \mathrm{~g}$ oral glucose tolerance test and adverse pregnancy outcomes. Diabetes Care. 2001;24:1151-5.

5. Lao TT, Tam KF. Gestational diabetes diagnosed in third trimester pregnancy and pregnancy outcome. Acta Obstet Gynecol Scand. 2001;80:1003-8.

Cite this article as: Sunita TH, Desai RM, Neravi A. Gestational diabetes mellitus diagnosed with single test glucose screening test and its outcome in a tertiary hospital in South India. Int J Reprod Contracept Obstet Gynecol 2015;4:1979-83. 